\section{Hvem tror du at hjernen din er?}

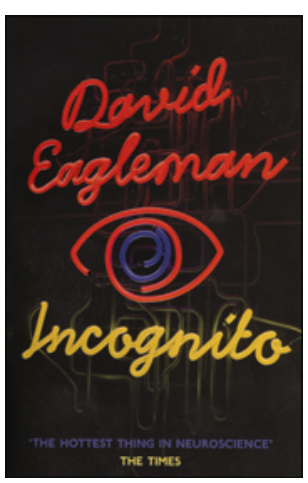

\author{
David Eagleman \\ Incognito \\ The secret lives of the brain. 290 s, ill. \\ Edinburgh: Canongate Books, 2012 \\ Pris GBP 9 \\ ISBN 978-1-84767-940-6
}

Ordet «inkognito» betyr «ukjent» og brukes særlig om en person som opererer med skjult identitet. Assosiasjonene går gjerne til spenningsromaner der en gåtefull mann i mørk frakk og solbriller driver handlingen frem med uforutsigbare planer og dulgte motiver. Hjerneforsker og forfatter David Eagleman ønsker å vise hvordan den viktigste aktiviteten i hjernen vår på en tilsvarende måte utføres i det skjulte av aktører som ikke gir seg til kjenne.

Incognito kom første gang på engelsk i 2011. Målgruppen er alle interesserte lesere, og det stilles ikke krav om bestemte forkunnskaper. Eagleman skriver sjangerbevisst og offensiv populærvitenskap. Disposisjonen er klar og pedagogisk, tonen lett og humoristisk. Forfatteren passer hele tiden på å knytte an til konkrete eksempler som leseren lett vil kunne kjenne seg igjen i.

Mange av disse eksemplene kan være ganske velkjente fra før. De fleste har hørt om «den blinde flekk» i synsfeltet og sett diverse eksempler på visuelle illusjoner. Man skal heller ikke bla i mange bøker om hjernen før man støter på historien om Phineas Gage, som fikk et metallstykke gjennom frontallappen og endret personlighet. Likevel er dette en medrivende bok, som har potensial til virkelig å ryste leserens verdensbilde. For kraften i Eaglemans tekst ligger ikke i det enkelte eksempel, men snarere i hvordan summen av dem alle tegner et nytt og avslørende bilde av hjernen og vårt mentale liv.

I dagliglivet tenker vi gjerne at sansene byr på en feilbarlig, men ganske pålitelig registrering av omgivelsene omkring oss. Vi opplever det som om hver av oss innehar en stabil og udelelig identitet, og vi tror vi har fullstendig innsikt i våre egne motiver og kan handle fritt ut i fra rasjonelt begrunnede valg. Forfatteren avslører alt dette som illusjoner. Det føles sånn, men det er ikke sånn hjernen virker.

Knut Hamsun ville i sin kjente programerklæring skrive om «det ubevisste sjeleliv». Sigmund Freud gjorde ideen om det underbevisste til kulturell fellesarv. Konseptet er således på ingen måte nytt, men Eagleman går lenger enn sine forgjengere. Når enkelte nevrale prosesser $\mathrm{i}$ hjernen får bli en del av vårt bevisste mentale liv, er det et marginalt fenomen - ikke omvendt.

Incognito er en velskrevet og fengslende bok. Den vil kunne føre til store aha-opplevelser, og glemmes ikke så lett av den som leser den. Samtidig er det et fascinerende paradoks at budskapet lett vil prelle av i praksis. Illusjonene forfatteren angriper, er så grunnleggende for vår måte å erfare verden på, at det knapt er mulig å gi slipp på dem i det daglige. Vi kan gripe hans argumenter med vår bevisste fornuft, men mektigere nevrale aktører, som opererer inkognito, vil nok likevel fortsatt sørge for å opprettholde illusjonen det meste av tiden hos de fleste av oss.

\section{Kognitive uttrykk ved hjernesykdommer}

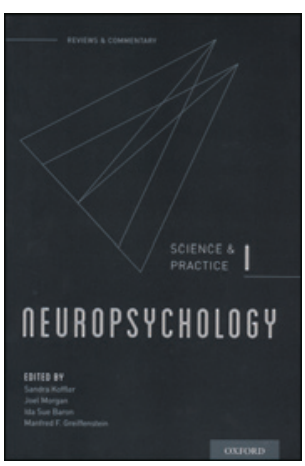

Sandra Koffler, Joel Morgan, Ida Sue Baron et al, red. Neuropsychology

Science \& practice, 1. $320 \mathrm{~s}$, tab, ill. Oxford Oxford University Press, 2013. Pris GBP 55 ISBN 978-0-19-979431-7

Boken er første bind i en planlagt serie av bøker om klinisk nevropsykologi. Arbeidsområdene til kliniske nevropsykologer er stadig voksende, men er ofte forankret $i$ arbeid med å kartlegge kognitiv funksjon ved hjerneskade (1) - både som ledd i diagnosesetting og i rehabiliteringsøyemed. Sentralt er bruken av nevropsykologiske (kognitive) tester av funksjonsnivå. Grove, klassiske tester, som trail making test (TMT) og mini-mental status (MMS), vil være kjent blant mange leger.

Hensikten med Neuropsychology er å tilby leserne en oppdatering fra den nevropsykologiske forskningsfronten.

Temaene går fra ny viten om traumatisk hjerneskade og posttraumatisk stresslidelse (PTSD) i kjølvannet av Irak- og Afghanistankrigene, til betydningen av kvantitativ hjerneavbilding i atferdsstudier. Hvert av de ti kapitlene er bygd opp som en enkeltstående, kort oversiktsartikkel med eget abstrakt. Kapitlene er nesten utelukkende forfattet av amerikanske eksperter. Et skandinavisk unntak er det fascinerende kapitlet om funksjonelle forskjeller mellom storhjernehemisfærene, hvor Kenneth Hugdahl ved Universitetet i Bergen er førsteforfatter

Det første kapitlet er et velkomment tema for nevropsykologiens posisjon i dagens helsevesen. I Evidence-based science and practice in neuropsychology forsøker forfatterne å se hvorvidt dagens nevropsykologiske fagfundament oppfyller idealene for evidensbasert medisin og praksis (EBM/EBP). Forfatterne konkluderer med at feltet har vært tregt i bruken av evidensbaserte standarder, især grunnet manglende konsensus for hvilke testbatterier som skal være gjengs.

Kapittel sju om strukturell hjerneavbilding er en god introduksjon til hvordan nevroradiologi i økende grad brukes for å studere samvariasjon mellom nevrobiologiske mål og nevropsykologiske testresultater - for eksempel hippocampusatrofi og verbal hukommelsesfunksjon hos demenspasienter.

Målgruppen er kliniske nevropsykologer og forskere innenfor nevrovitenskapene. Samtidig vil boken være interessant for leger og andre som er nysgjerrige på status quo i studiet av sammenhengen mellom hjernesykdommer og kognisjon. Boken er faglig solid og dekker på en konsis måte relevante deler av den nevropsykologiske forskningsfronten.

Det store spranget mellom de ulike kapitlenes tematikk gjør at boken ikke har noen rød tråd. Den tjener isteden mer som en twistskål med et utvalg sentrale smakebiter fra hva nevropsykologi i 2013 har å by på. For en lærebok i nevropsykologi bør leseren heller rette blikket mot fagfeltets ubestridte bibel - Neuropsychological assessement (1).

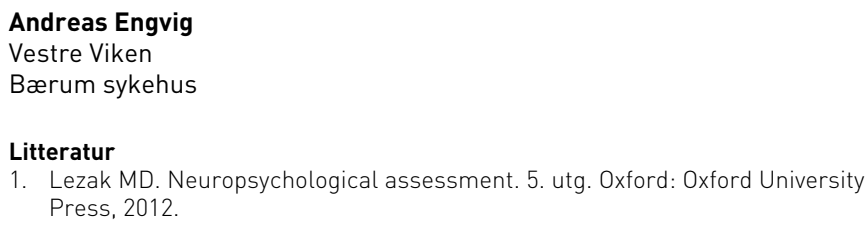

